\title{
Genetic diversity of strawberry cultivars in Banyuroto, Magelang, Indonesia based on Cleaved Amplified Polymorphic Sequence
}

\author{
MUHAMMAD FAUZI ARIF ${ }^{1}$, GANIES RIZA ARISTYA ${ }^{2, \boldsymbol{v}}$, RINA SRI KASIAMDARI ${ }^{3}$ \\ ${ }^{1}$ Departement of Tropical Biology, Faculty of Biology, Universitas Gadjah Mada. Special Region of Yogyakarta 55281, Indonesia. \\ ${ }^{2}$ Laboratory Genetics and Breeding, Faculty of Biology, Universitas Gadjah Mada. Special Region of Y ogyakarta 55281, Indonesia. \\ Tel.+62-274-580839,vemail: ganies_riza@ugm.ac.id \\ ${ }^{3}$ Laboratory of Plant Systematics, Faculty of Biology, Universitas Gadjah Mada. Special Region of Yogyakarta 55281, Indonesia,
}

Manuscript received: 19 March 2019. Revision accepted: 27 May 2019.

\begin{abstract}
Arif MF, Aristya GR, Kasiamdari RS. 2019. Genetic diversity of strawberry cultivars in Banyuroto, Magelang, Indonesia based on Cleaved Amplified Polymorphic Sequence. Biodiversitas 20: 1721-1728. Banyuroto Village, Magelang, Central Java is the center of strawberry (Fragaria spp.) development and cultivation program. The mild climate makes the location very suitable for developing sub-tropic horticulture such as strawberry. Various kinds of cultivars have been developed as part of the agrotourism program. However, genetic variation research of those cultivars is still rarely done. Therefore, the molecular study of strawberry was conducted to determine the genetic variation using CAPS markers. DNA of Five strawberry cultivars from Banyuroto and seven strawberry cultivars from Indonesian Citrus and Subtropical Fruits Research Institute, Malang were isolated using the CTAB method. DNA amplification was performed by PCR using four pairs of primers named APx, OLP, F3H2, and CTI2. The amplification results were cut with three kinds of restriction endonuclease enzymes named $M b o \mathrm{I}, M l u \mathrm{I}$, and TaqI. Restriction product was used to analyze the genetic variation of twelve cultivars and to construct the dendrogram using MVSP software with the UPGMA algorithm. The result showed that the percentage of polymorphic was $45 \%$ from 9 polymorphic bands. Dendrogram result showed that there were four clusters. Cluster A consists of Stroberi Hitam, Cluster B consists of Californica Cultivars, cluster C consists of Osso Grande and Osso Purbalingga cultivars, and cluster D consists of Rosalinda, Deeprose, Dorit, Earlibrite, Tristar, Festival, Brastagi, and Aerut. This research concluded that CAPS markers can be used as a method for study genetic diversity of strawberries.
\end{abstract}

Keywords: CAPS, Fragaria, genetic variation, molecular markers, strawberry, restriction enzyme

Abbreviations: CAPS: Cleaved Amplified Polymorphic Sequence, PCR: Polymerase chain reaction, MVSP: MultiVariate Statistical Package, SNP: Single Nucleotide Polymorphisms

\section{INTRODUCTION}

Banyuroto Village, Magelang is the center of strawberry development in Central Java, Indonesia (Aristya et al. 2017). It is located on the valley of Merabu, with an altitude of around $1300 \mathrm{~m}$ above sea level (Falah et al. 2018). The mild climate makes the location very suitable for developing sub-tropic horticulture such as strawberry. There are several cultivars developed for agrotourism programs. The development is carried out in order to improve the quality of strawberry production which continues to decrease. It is also helpful for improving the living standards of natives there.

According to Suhariyanto (2015) data, Indonesia still needs to import strawberries from other countries because it has not been able to fulfil the market demands that have increased yearly. Strawberries consumed by the public today are cross-products of various kinds of progenitors (Faedi et al. 2002). Each of them has different phenotype characters. Phenotypic variations indicate genetic variation up to the molecular level. Analysis of variations up to the molecular level will help strawberry farmers deal with their agricultural problems. Molecular variation is characterized by the presence of polymorphisms (Qi et al. 2014). The numbers of developed cultivars make the genetic variation of strawberry is an interesting topic to research and to explore. Aristya et al. (2019) has analyzed the genetic diversity of strawberries cultivated in Banyuroto Village, Magelang using RAPD markers. The result showed that there are several polymorphisms which can be detected specifically. However, to improve the result, we still need other research using other molecular markers.

Molecular markers are a technique that can be used to detect genetic variation, genetic inheritance, allele combinations, and genetic polymorphism in a group of plants (Hussain et al. 2015). It also can be used as a tool for phenetic and phylogenetic analysis. There are several kinds of molecular markers that can be applied. Each of the markers has its own advantages and disadvantages (Weising et al. 2005). CAPS has a simple principle (Shavkurov 2015). CAPS is developed from conventional RFLP technique. PCR product from gen of interest is cut using restriction enzyme, then separated using gel agarose (Lu et al. 2010). CAPS is co-dominant, which makes homozygous and heterozygous individuals are easily recognized. This technique provides advantages in genetic studies and a perfect fit as an additional tool for more detailed and accurate analyses (Akbari et al. 2006). Kunihisa et al. (2006) stated that this method provides stable results and highly reproducible especially for 
detecting polymorphisms in strawberries.

The primers used in this study were compiled from research conducted by Kunihisa et al. (2005). The primers amplify genes that play an important role for the strawberries. In this study four pairs of primers named APx, OLP, CTI2, and F3H2 were used. Each primer consists of a forward and reverse primer. Therefore, amplified DNA was produced in a specific fragment that encoded a particular gene. The APx primer amplified the gene encoding the ascorbate peroxidase enzyme. The OLP primer amplified the gene encoding osmotin like protein. The CTI2 primer amplified the chitinase enzyme-coding gene. The $\mathrm{F} 3 \mathrm{H} 2$ primer amplified the flavanone 3hydroxylase coding gene. According to Caverzan et al. (2012), ascorbate peroxidase enzyme is an enzyme that catalyzes the conversion of $\mathrm{H}_{2} \mathrm{O}_{2}$ into $\mathrm{H}_{2} \mathrm{O}$ because of its ability to provide electron donors. Plants that experience environmental stress will produce Reactive Oxygen Species (ROS), which can damage their own cells. The presence of ascorbate peroxidase enzyme makes plants able to detoxify $\mathrm{H}_{2} \mathrm{O}_{2}$ through the cycle of ascorbateglutathione. Osmotin like protein is produced when plants experience injury, response to ethylene, environmental stress, or defense against pathogens ( $\mathrm{Zu}$ et al. 1995). Increased of Osmotin Like Protein has been shown to increase resistance against pathogens such as bacteria fungi, and viruses. The chitinase enzyme is produced by plants as a self-defense response from attacks of fungal and insects. The chitinase enzyme is able to degrade chitin which is the main structure of fungi's cells and insect's cells (Sharma et al. 2011). Flavanone 3-hydroxylase is one of the nuclear enzymes that has the role to catalyze the formation of flavonoid reaction pathways such as naringenin to dehydroflavonol (Britsch and Grisebach 1986). Flavonoids play an important role in plant selfdefense systems in the environment.

The purpose of this study is to study the genetic diversity of strawberry cultivars in Banyuroto Village using CAPS molecular markers.

\section{MATERIALS AND METHODS}

\section{Study area}

This study used twelve strawberry cultivars. Five strawberry cultivars were collected from Banyuroto Village, Magelang, Central Java and seven strawberry cultivars were collected from Indonesian Citrus and Subtropical Fruits Research Institute, Malang, East Java. (Table 1). The fifth young leaf from each cultivar was used to be extracted. There were four pairs of primers used for this study (Table 2). Three kinds of restriction enzyme with different cut-off points were used to cut the amplification product (Table 3).

\section{Procedures}

\section{DNA extraction}

Samples were stored at $-20^{\circ} \mathrm{C}$. DNA was extracted from leaves of each cultivar using the modified CTAB method (Doyle and Doyle 1987). 0.1 gram samples were ground using mortar and pestle. Liquid nitrogen was used to make it easier. Ground samples were placed into 1.5 microtube. 0.02 gram of PVP and $700 \mu \mathrm{L}$ of $2 \%$ CTAB (1M Tris- $\mathrm{HCl}$; $0.5 \mathrm{M}$ EDTA; $5 \mathrm{M} \mathrm{HCl} ; 0,2 \% \quad \beta$-mercaptoethanol) were added into microtube. Samples were incubated at $65^{\circ} \mathrm{C}$ for $15 \mathrm{~min} .700 \mu \mathrm{L}$ of chloroform-isoamyl alcohol (24: 1) was added into the mixture, and then all of the samples were homogenized for $30 \mathrm{~min}$. Samples were centrifuged at $13.000 \mathrm{rpm}$ for $10 \mathrm{~min}$. The formed supernatant was moved into the new microtube. Cold isopropanol was added into the supernatant with ratio 1: 1 . Samples were precipitated for $60 \mathrm{~min}$. After that, the samples were centrifuged at $13,000 \mathrm{rpm}$ for $10 \mathrm{~min}$. Formed pellets were washed by using ethanol absolute for two times. The washing process was done by centrifuging samples at $13,000 \mathrm{rpm}$ for 10 min. The pellets were dissolved in $50 \mu \mathrm{L}$ TE buffer solution and stored at $-20^{\circ} \mathrm{C}$. The modified methods were adding PVP, incubation time and temperature, and centrifugation speed and time.

Table 1. Strawberry cultivars used in the study

\begin{tabular}{lll}
\hline Cultivars & Species & Origin of sample \\
\hline 'Californica' & $F$. vesca L. & Banyuroto, Magelang \\
'Earlybrite' & $F . \times$ ananassa Duch. & Banyuroto, Magelang \\
'Rosalinda' & $F . \times$ ananassa Duch. & Banyuroto, Magelang \\
'Tristar' & $F . \times$ ananassa Duch. & Banyuroto, Magelang \\
Stroberi Hitam & $F$. moschata Duch. & Banyuroto, Magelang \\
'Aerut' & $F . \times$ ananassa Duch. & ICSFRI, Malang \\
'Berastagi' & $F . \times$ ananassa Duch. & ICSFRI, Malang \\
'Dorit' & $F . \times$ ananassa Duch. & ICSFRI, Malang \\
'Deeprose' & $F . \times$ ananassa Duch. & ICSFRI, Malang \\
'Festival' & $F . \times$ ananassa Duch. & ICSFRI, Malang \\
'Oso Grande' & $F . \times$ ananassa Duch. & ICSFRI, Malang \\
'Oso Purbalingga' & $F . \times$ ananassa Duch. & ICSFRI, Malang \\
\hline
\end{tabular}

Table 2. Primers and sequence of primers used in this study (Kunihisa et al. 2005)

\begin{tabular}{ll}
\hline Primers & \multicolumn{1}{c}{ Primer Sequence 5'-3' } \\
\hline CT12 & Forward GTCAAACCTCTCACGAAACCACT \\
& Reverse GTTRCTAAGAAAATGAAAGAGCTGATG \\
OLP & Forward TGTGTCCAAAACCGATCAGTATTGC \\
& Reverse TCTTTCAGAGTGGTACGTACCCC \\
F3H & Forward TAATAGGGTCTAGGTGCGTGG \\
& Reverse GAGTTCACTACKGCCTGGTGATC \\
APX & Forward GTGGTCACACCTTGGTGC \\
& Reverse AGTATAATATTTAAGCAGAATGCAGACTTC \\
\hline
\end{tabular}

Table 3. Restriction Enzymes used and its cut-off point (Kunihisa et al. 2005)

\begin{tabular}{|c|c|c|}
\hline $\begin{array}{l}\text { Restriction } \\
\text { enzymes }\end{array}$ & Cut-off point & $\begin{array}{l}\text { Incubation } \\
\text { temp. }\left({ }^{\circ} \mathrm{C}\right)\end{array}$ \\
\hline MboI & 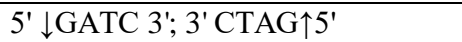 & 37 \\
\hline MluI & $5^{\prime}$ A $\downarrow C G C G$ T 3'; 3' T GCGC $\uparrow A 5^{\prime}$ & 37 \\
\hline TaqI & 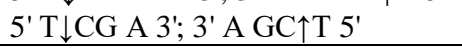 & 60 \\
\hline
\end{tabular}


Quantitative analysis using spectrophotometry

Each of isolated DNA was analyzed using nanodrop spectrophotometry UV Vis. A total of $2 \mu \mathrm{L}$ DNA was taken from the microtube. The isolate was dripped into the spectrophotometer (NanoVue Plus). The process was done 3 times for each cultivar for the repetition. Each repetition was taken from a different individual. The average DNA concentration and purity were calculated.

\section{DNA amplification}

DNA amplification was performed with four pairs of the primer by PCR (Table 2). Each reaction contained 12,5 $\mu \mathrm{L}$ KAPA hot start ready-mix, $1 \mu \mathrm{L}$ forward primer, $1 \mu \mathrm{L}$ reverse primer, $8,5 \mu \mathrm{L}$ nuclease-free water, and $2 \mu \mathrm{L}$ DNA template. The template concentration was $10 \mathrm{ng} / \mu \mathrm{L}$ and the primers concentration was $25 \mu \mathrm{M}$. PCR was carried out by several processes using thermal cycler (Veriti Thermal Cycler, Applied Biosystems). Pre-denaturation temperature was $95^{\circ} \mathrm{C}$ for $3 \mathrm{~min}$, denaturation temperature was $95^{\circ} \mathrm{C}$ for 30 secs, annealing temperature was $54^{\circ} \mathrm{C}-58^{\circ} \mathrm{C}$ for 30 secs, elongation temperature was $72^{\circ} \mathrm{C}$ for $1 \mathrm{~min}$, postelongation temperature was $72^{\circ} \mathrm{C}$ for $1 \mathrm{~min}$, and hold temperature was $4^{\circ} \mathrm{C}$. Denaturation-elongation processes were repeated up to 40 cycles. Amplicons were visualized using electrophoresis with $2 \%$ agarose gel.

\section{Digestion of amplicons}

Each of amplicons was given restriction enzyme treatment. Each reaction contains $3.5 \mu \mathrm{L}$ of nuclease-free water, $1 \mu \mathrm{L}$ of reaction buffer, $5 \mu \mathrm{L}$ of amplicon, and 0.5 $\mu \mathrm{L}$ of restriction enzyme $(4 \mathrm{U})$. Samples were incubated using thermocycler for $120 \mathrm{~min}$ with specific temperature (Table 3). Restriction products were separated and visualized using electrophoresis with $2 \%$ agarose gel.

\section{Data analysis}

The polymorphic percentage was calculated using the band's pattern. Restriction products were converted into a matrix using Microsoft Excel. DNA bands were converted into the binary matrix. Present bands were converted into "1" and absent bands were converted into " 0 ". The dendrogram was constructed with Jaccard's coefficient using the Unweighted Pair-Group Using Arithmetic Average (UPGMA) algorithm on Multi-Variate Statistical Average (MVSP) 3.22 software.

\section{RESULTS AND DISCUSSION}

\section{DNA Isolation of Strawberry Cultivars}

In this study, the modified CTAB method successfully isolated all 12 cultivars. The isolated DNA was generally large in size. Isolated DNA was larger than $10 \mathrm{~kb}$. This can be seen on the results of agarose gel electrophoresis with $0.8 \%$ concentration (Figure 1). Generally, the successfully isolated genomic DNA has not moved far because of its large size. The larger the molecular size, the slower the transfer rate at the agarose. The average concentration and purity of isolated DNA were shown in Table 4. Various level of concentration was detected. The lowest concentration was on 'Tristar' with an average of $174.83 \pm$ $30.15 \mathrm{ng} / \mu \mathrm{L}$. The highest concentration was on 'Earlybrite' with an average of $1174.33 \pm 46.47 \mathrm{ng} / \mu \mathrm{L}$. The purity result (Table 4) showed that all of the isolated were pure and free from contaminants. All of the DNA purity was near to 1.8 .

\section{DNA Amplification of CAPS Markers}

We have successfully amplified all of the samples using 4 pairs of primer. The size of amplified fragments was different for each primer (Figure 2; Table 6). The APx primer amplified the target with $567 / 488$ bp length. The OLP primer amplified the target by 520 bp length. The CTI2 primer amplified the target by 312 bp length. The F3H2 primer amplified the target by 390 bp length.

\section{Digestion of amplicons using restriction enzyme}

From this study, 4 pairs of primer and 3 restriction enzymes produced in 12 cutting combinations. Not all of the enzymes can cut the amplicons. From the 12 presented cutting combinations, five of them did not produce a cut pattern (Table 6). Each strawberry cultivar also provided a different and unique cutting pattern (Figure 2). Amplicon which was successfully cut will be reduced in size according to its initial size.

Table 4. The quantitative analysis result of DNA from 12 cultivars with 3 repetition

\begin{tabular}{lll}
\hline Cultivars & $\begin{array}{l}\text { Concentration } \\
(\mathbf{n g} / \boldsymbol{\mu L} \mathbf{L})\end{array}$ & $\begin{array}{l}\text { Purity } \\
(\mathbf{\AA} 260 / \mathbf{A} 280)\end{array}$ \\
\hline 'Californica' & $656.50 \pm 85.62$ & $1.98 \pm 0.05$ \\
'Earlybrite' & $1174.33 \pm 46.47$ & $1.99 \pm 0.02$ \\
'Rosalinda' & $269.67 \pm 51.69$ & $1.83 \pm 0.04$ \\
'Tristar' & $174.83 \pm 30.15$ & $1.80 \pm 0.05$ \\
Stroberi Hitam & $526.50 \pm 47.56$ & $1.64 \pm 0.06$ \\
'Aerut' & $1157.83 \pm 210.16$ & $1.81 \pm 0.06$ \\
'Berastagi' & $589.33 \pm 108.44$ & $2.02 \pm 0.03$ \\
'Dorit' & $852.33 \pm 8.08$ & $1.75 \pm 0.12$ \\
'Deeprose' & $528.83 \pm 199.95$ & $1.83 \pm 0.10$ \\
'Festival' & $838.83 \pm 118.74$ & $1.93 \pm 0.13$ \\
'Oso Grande' & $823.50 \pm 172.66$ & $1.94 \pm 0.04$ \\
'Oso Purbalingga' & $530.00 \pm 130.05$ & $1.88 \pm 0.02$ \\
\hline
\end{tabular}

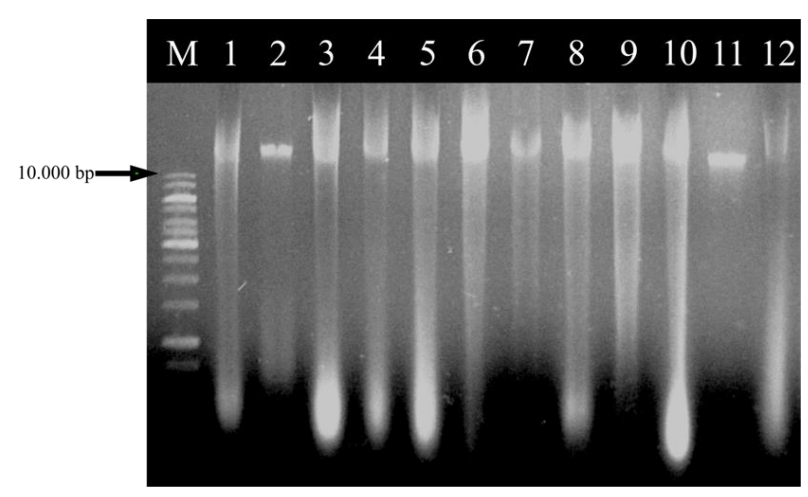

Figure 1. Electrophoresis of DNA Genome of 12 strawberry cultivars. Note: M1: 1 kb marker, 1: Aerut, 2: Brastagi, 3: Californica, 4: Earlibrite, 5: Dorit, 6: Deeprose, 7: Festival, 8: Stroberi Hitam, 9: Rosalinda, 10: Tristar, 11: Osso Purbalingga, 12: Osso Grande 

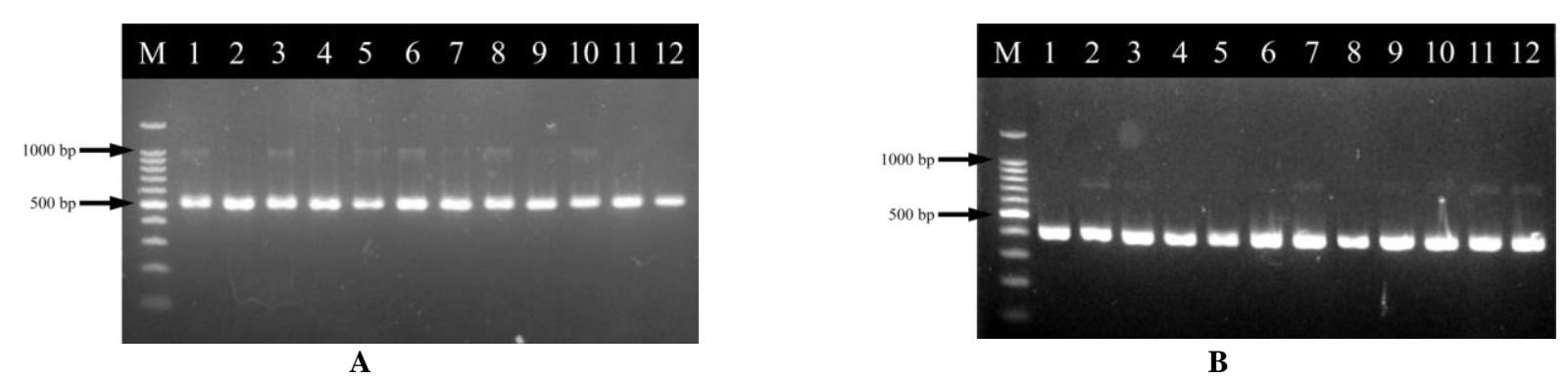

B

Figure 2. Amplicons of (A) OLP primer and (C) F3H2 primer. M1: 100 bp marker, 1: Aerut, 2: Brastagi, 3: Californica, 4: Earlibrite, 5: Dorit, 6: Deeprose, 7: Festival, 8: Stroberi Hitam, 9: Rosalinda, 10: Tristar, 11: Osso Purbalingga, 12: Osso Grande. Note: Not all of the data are shown
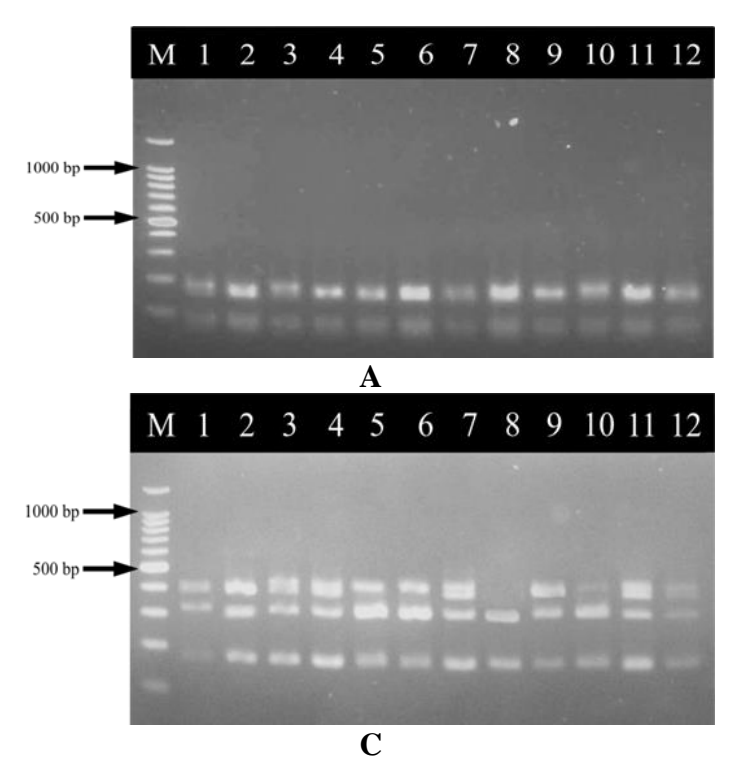

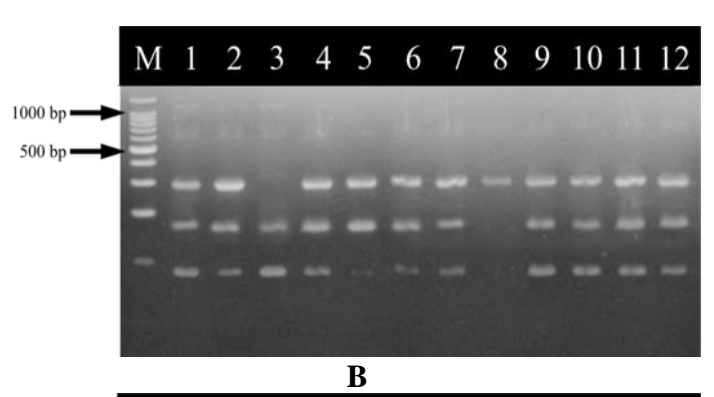

$\begin{array}{llllllllllllll}\mathrm{M} & 1 & 2 & 3 & 4 & 5 & 6 & 7 & 8 & 9 & 10 & 11 & 12\end{array}$

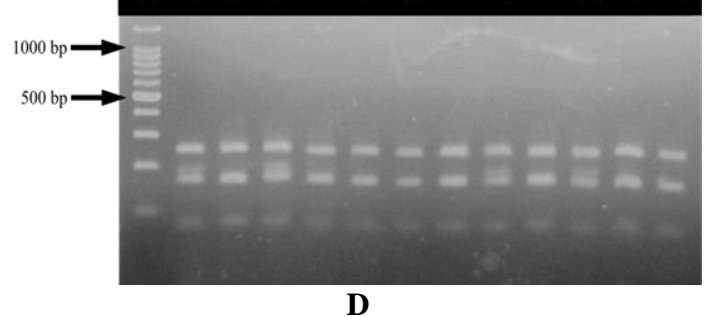

Figure 3. Restriction products of (A) OLP-TaqI, (B) CTI2-MluI, (C) APx-TaqI, and (D) OLP-MboI. M1: 100 bp marker, 1: Aerut, 2: Brastagi, 3: Californica, 4: Earlibrite, 5: Dorit, 6: Deeprose, 7: Festival, 8: Stroberi Hitam, 9: Rosalinda, 10: Tristar, 11: Osso Purbalingga, 12: Osso Grande. Note: Not all of the data are shown

Table 5. Percentage of polymorphism of CAPS markers

\begin{tabular}{lcccc}
\hline $\begin{array}{l}\text { Primers- } \\
\text { restriction } \\
\text { enzyme }\end{array}$ & $\begin{array}{c}\text { Total } \\
\text { numbers } \\
\text { of DNA } \\
\text { bands }\end{array}$ & $\begin{array}{c}\text { Mono- } \\
\text { morphic } \\
\text { bands }\end{array}$ & $\begin{array}{c}\text { Poly- } \\
\text { morphic } \\
\text { bands }\end{array}$ & $\begin{array}{c}\text { Percentage of } \\
\text { polymorphism }\end{array}$ \\
\hline CTI2-Mlul & 3 & 2 & 1 & $33 \%$ \\
F3H2-MluI & 3 & 0 & 3 & $100 \%$ \\
OLP-MboI & 3 & 3 & 0 & $0 \%$ \\
APX-TaqI & 3 & 2 & 1 & $33 \%$ \\
APX-MluI & 3 & 2 & 1 & $33 \%$ \\
CTI2-MboI & 3 & 0 & 3 & $100 \%$ \\
OLP-TaqI & 2 & 2 & 0 & $0 \%$ \\
Total & 20 & 11 & 9 & $45 \%$ \\
\hline
\end{tabular}

Digested amplicons gave a total of 20 DNA bands with different sizes. The total number of the monomorphic band was 11 . The total number of the polymorphic band was 9 . Based on that result, it can be seen that the CAPS molecular marker gave the polymorphic percentage of $45 \%$
(Table 5).

After digested using three kinds of enzyme, each of amplicon were visualized on the agarose gel (Figure 3). Digested amplicons gave different length result from the original amplicon bands (Table 6). The original size of APX amplicon was $567 / 488$ bp. Different cultivar resulting a different amplicon size. After digested using TaqI and MluI enzyme, the band's size was 387/305/152 bp and $567 / 489 / 395$ bp. The APx amplicons cannot be digested by MboI enzyme. The original OLP amplicon size was $520 \mathrm{bp}$. After digested using TaqI and $\mathrm{MboI}$ enzyme, it digested into about $156 / 99 \mathrm{bp}$ and $250 / 155 / 82 \mathrm{bp}$. The OLP amplicons cannot be digested by MluI enzyme. The CTI2 amplicons original size were 312 bp. After digested using MluI and MboI, its size became 312/178/92 bp and 312/170/89 bp respectively. The CTI2 amplicons cannot be digested by $T a q \mathrm{I}$ enzyme. The original size of $\mathrm{F} 3 \mathrm{H} 2$ amplicons were 390. After digested using MluI enzyme, its size became 384/242/119 bp. The F3H2 amplicons cannot be digested by $M b o \mathrm{I}$ and $M l u \mathrm{I}$ enzyme. 
Table 7. Estimate genotype of each cultivar from the digested pattern

\begin{tabular}{|c|c|c|c|c|c|c|c|c|c|c|c|c|}
\hline \multirow[b]{2}{*}{$\begin{array}{l}\text { Primer- } \\
\text { enzyme }\end{array}$} & \multicolumn{12}{|c|}{ Cultivars } \\
\hline & $\sum_{0}^{ \pm}$ & 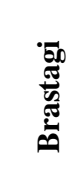 & نَّ & 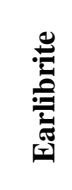 & : & 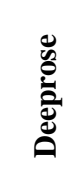 & 矛 & 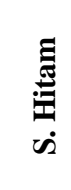 & 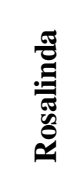 & 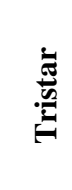 & 总 & 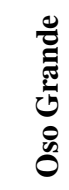 \\
\hline CTI2-Mlul & HR & HR & HM & HR & HR & HR & HR & HM & HR & HR & HR & HR \\
\hline F3H2-MluI & HM & $\mathrm{HM}$ & $\mathrm{HR}$ & HM & HM & HM & HM & HM & HM & HM & $\mathrm{HR}$ & HR \\
\hline OLP-MboI & HR & HR & $\mathrm{HR}$ & HR & HR & HR & HR & HR & HR & $\mathrm{HR}$ & HR & HR \\
\hline APx-TaqI & $\mathrm{HR}$ & $\mathrm{HR}$ & $\mathrm{HR}$ & $\mathrm{HR}$ & $\mathrm{HR}$ & $\mathrm{HR}$ & $\mathrm{HR}$ & $\mathrm{HM}$ & $\mathrm{HR}$ & $\mathrm{HR}$ & $\mathrm{HR}$ & HR \\
\hline APx-MluI & $\mathrm{HR}$ & $\mathrm{HR}$ & $\mathrm{HM}$ & $\mathrm{HM}$ & HM & HM & $\mathrm{HR}$ & HM & HM & $\mathrm{HR}$ & $\mathrm{HM}$ & HM \\
\hline CTI2-MboI & $\mathrm{HR}$ & $\mathrm{HR}$ & HM & HR & $\mathrm{HR}$ & HR & $\mathrm{HR}$ & HM & $\mathrm{HR}$ & $\mathrm{HR}$ & $\mathrm{HR}$ & $\mathrm{HR}$ \\
\hline OLP-TaqI & $\mathrm{HM}$ & HM & $\mathrm{HM}$ & $\mathrm{HM}$ & $\mathrm{HM}$ & $\mathrm{HM}$ & $\mathrm{HM}$ & HM & $\mathrm{HM}$ & $\mathrm{HM}$ & $\mathrm{HM}$ & $\mathrm{HM}$ \\
\hline
\end{tabular}

Note: HR: Heterozygote, HM: Homozygote

Table 6. Restriction products length of CAPS markers

\begin{tabular}{llll}
\hline Primer & $\begin{array}{l}\text { Restriction } \\
\text { enzyme }\end{array}$ & $\begin{array}{l}\text { Amplicon } \\
\text { length }\end{array}$ & $\begin{array}{l}\text { Restriction } \\
\text { length }\end{array}$ \\
\hline \multirow{3}{*}{ APx } & TaqI & $567 / 488$ & $387 / 305 / 152$ \\
& MluI & $567 / 488$ & $567 / 489 / 395$ \\
& MboI & $567 / 488$ & - \\
OLP & TaqI & 520 & $156 / 99$ \\
& MluI & 520 & - \\
& MboI & 520 & $250 / 155 / 82$ \\
CTI2 & TaqI & 312 & - \\
& MluI & 312 & $312 / 178 / 92$ \\
& MboI & 312 & $312 / 170 / 89$ \\
F3H2 & TaqI & 390 & - \\
& MluI & 390 & $384 / 242 / 119$ \\
& MboI & 390 & - \\
\hline
\end{tabular}

Note: "-" indicated that the amplicons cannot be cut by the restriction enzymes

Digested patterns can be used as a tool to estimate the type of genotype from each cultivar. If there are two different types of digested patterns resulted from one digestion enzyme, it can be assumed that the cultivar is heterozygous. If there is just one kind of digested pattern resulted from a digestion enzyme, it can be assumed that the cultivar is homozygous (Konieczny and Ausubel 1993). The assumed genotype can be seen in Table 7.

\section{Dendrogram result between 12 strawberry cultivars}

Based on the dendrogram result (Figure 4), twelve cultivars of strawberry were grouped into 3 clusters. Cluster I consists of Stroberi Hitam which has $63 \%$ similarity with the other cluster. Cluster II consists of Californica cultivar which has $84 \%$ similarity with cluster III. Cluster III consist of 10 cultivars which are Osso Grande, Osso Purbalingga, Rosalinda, Deeprose, Dorit, Earlibrite, Tristar, Festival, Brastagi, and Aerut. The dendrogram was constructed using Jaccard's coefficient with the UPGMA algorithm.

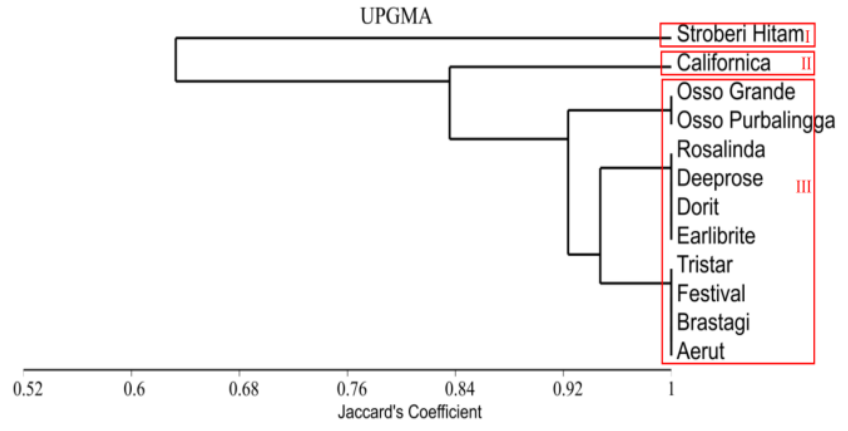

Figure 4. Dendrogram constructed between 12 strawberry cultivars

\section{Discussion}

DNA Isolation of 12 Strawberry Cultivars

Leaf was used as the DNA source for extraction in this study. We used young leaves. According to Achakzai et al. (2009) older leaf generally produces higher amounts of polyphenols, tannins, and polysaccharides than the young ones. These compounds reduce the quality of isolated DNA. Polysaccharides tend to bind nucleic acids in low ionic buffers (Wang and Stegemann 2010). This made the isolated pellets thick and textured like glue. If those happened, the pellets would be difficult to pipette and also interfered the activity of Taq polymerase enzyme in the PCR reaction (Spangler et al. 2009). Our isolation method used CTAB as the main material for extracting DNA from the cell nucleus. PVP was added which acted as a strong antioxidant that prevented the binding of DNA and polyphenols (Puchooa 2004). $\beta$-mercaptoethanol also used as the mixture component of CTAB to prevent the occurrence of polyphenol oxidation and disulfide bonds (Chang et al. 1993). Isopropanol precipitated DNA by the mechanism of dehydration. The water content in DNA can be deposited because the solubility is lowered than isopropanol by pulling out water from the DNA. Therefore, isopropanol made the solubility of DNA was decreased. The formed pellet was stored into Tris-EDTA buffer until ready for amplification. 
The quantitative analysis was done using spectrophotometry UV Vis to measure DNA concentration and purity. The DNA and the contaminant molecules absorb different wavelength specifically (Nunes et al. 2011). The wavelength data were converted to measure concentration and purity. Our modification method success isolated DNA with a high amount of concentration and purity (Table 4). This made we must perform DNA dilution using TE buffer for PCR reaction. The average concentration yield was various for each cultivar. The $\AA 260 / \AA 280$ ratios were nearly 1.8 . That indicated that the isolated DNA was not free from contaminants but still can be used for PCR reaction. The $\mathrm{pH}$ of the solution will lead the $\AA 260 / \AA 280$ to be different (Wilfinger et al. 1997). The presence of EDTA in the solution of DNA also might interfere with the absorbance in wavelengths of $280 \mathrm{~nm}$ (Nunes et al. 2011).

\section{DNA Amplification of CAPS Markers}

DNA amplification was done by PCR technique. The PCR technique can multiply the specific fragment of nucleic acid by regulating the reaction temperature (Joshi and Deshpande 2010). The double-stranded DNA was denatured into a single-stranded DNA when it was given high-temperature treatment (around $94^{\circ} \mathrm{C}$ or more). Right after denatured, the DNA was given a low-temperature treatment (around $37^{\circ} \mathrm{C}$ ) then the target primer attachment would begin. The Taq polymerase enzyme extended the primer sequence attached to the DNA template through 5'3 direction (Campbell et al. 2008). All of the components for amplification such as Taq polymerase enzyme, dNTP, $\mathrm{MgCl}_{2}$, and loading dye were gathered in the PCR kit. This research used $10 \mathrm{ng} / \mu \mathrm{L}$ concentration of DNA template. The concentration level of DNA templates and primers influence the success of the DNA amplification process (Lorenz 2012). Kunihisa et al. (2005) stated that the CAPS marker did not require a high concentration of DNA.

\section{Digestion of amplicons using restriction enzyme}

Restriction enzymes have a different cut off point which able to recognize certain sequences to cut. Each restriction enzyme generally has 4 to 6 identification sequences (Roberts et al. 2003). The recognition site of restriction enzymes makes the enzyme only able to cut DNA fragments in certain parts specifically. Restriction enzymes were incubated at $37^{\circ} \mathrm{C}$ for $M l u \mathrm{I}$ and $M b o \mathrm{I}$, while the TaqI enzyme was incubated at $60^{\circ} \mathrm{C}$. Incubation process was done for 6 hours to complete the restriction process. The difference in incubation temperature is caused due to differences in the origin of the enzyme obtained. The TaqI enzyme required a higher incubation temperature because it was obtained from the thermophilic bacteria Thermus aquaticus YT I (Sato 1978). The MboI enzyme was obtained from the Moraxella bovis bacteria and the MluI enzyme was obtained from the Micrococcus luteus (Gelinas 1977).

Based on the results obtained in this study (Table 6), not all of the enzymes were able to cut amplified fragments. This can happen because the amplified fragments do not have sequences capable of being recognized by the restriction enzymes. Restriction enzyme works by inspecting the DNA sequence to find its specific recognition sequence. If it cannot find the specific recognition sequence, it will not bind to the DNA and the two strands of the double helix cannot be cut (BuckhoutWhite et al. 2018). The TaqI enzyme was only able to cut APx and OLP amplification fragments. The MluI enzyme was able to cut APx, CTI2 and $\mathrm{F} 3 \mathrm{H} 2$ amplification fragments. The MboI enzyme only cut OLP and CTI2 amplification fragments. These things ensure that the CAPS marker method is very specific. Therefore, CAPS markers can be used as an alternative for SNP analysis with large sample quantities. The polymorphism can be analyzed without the sequencing process (Shavrukov 2016). SNP has a very important function as a molecular marker that describes the level of genetic variation and genetic changes made by breeders (Edwards and Batley 2010).

\section{Dendrogram and similarity index between 12 strawberry cultivars}

Based on the dendrogram result (Figure 4), three cluster groups were obtained. The grouping and clustering pattern illustrated how the sequence differences from the four primers using for amplification. Research on genetic variation in strawberry cultivars has been done previously by Aristya et al. (2019) using the RAPD marker. In that study, strawberries are grouped into two large clusters separated according to the morphological character types of each individual. In addition, the results of cluster grouping in the study showed a close similarity relationship between cultivars with the same number of chromosomes. In this study, clusters formed also follows the pattern of the origin of each cultivar. This is related to the inheritance of genetic material from the parent to the offspring. Strawberries 'Osso Grande', 'Osso Purbalingga', 'Aerut', 'Brastagi', 'Californica', 'Earlibrite', 'Dorit', 'Deeprose', 'Rosalinda', and 'Tristar' are grouped in a cluster because the digested fragments have a similarity value of $95 \%$. All of these cultivars are individuals classified into $F$. $\times$ ananassa Duch. This hybrid results from a cross between species from North America, namely $F$. virgiana Duch. and species from Chile, F. chiloensis (L.) Mill (Chandler 2012). The possibility that causes a small difference in these cultivars is the presence of environmental factors. All primers used in this study amplified genes that play a role in defence mechanisms from pathogens and environmental stresses. Excessive environmental stress can cause genetic mutations in the form of insertions or deletions (Elena and Viser 2013). The strawberry 'Osso Purbalingga' is cultivated of the 'Osso Grande' strawberry in the Purbalingga area. This makes the two cultivars have more similar value compared to the eight others cultivars. Stroberi Hitam and 'Californica' strawberry were separated from the ten other cultivars. Unlike the other cultivars, both of them are not hybrids.

The clustering results in the twelve strawberry cultivars also grouped following the number of ploidy of each cultivar. Hancock et al. (2008) stated that 'Aerut', 'Brastagi', 'Festival', 'Tristar', 'Earlibrite', 'Dorit', 
'Deeprose', 'Rosalinda', Osso Grande, and Osso Purbalingga are octaploid individuals $(2 n=8 x=56)$. The 'Californica' is diploid individuals $(2 n=2 x=16)$. It was separated from the previous ten cultivars. Stroberi Hitam which are the furthest separated cultivars with the eleven other cultivars is hexaploid individuals $(2 n=6 x=48)$. It came from allopolyploidization or autopolyploidization is still unclear. Strawberries are still actively cultivated and hybridized by humans. This makes strawberries have many variations in the number of chromosome sets. Kunihisa et al. (2005) stated that CAPS markers can detect the polymorphic bands from the octaploid cultivars. Cultivars with less number of alleles have low dose of alleles that can generate polymorphic bands among them. Some of cultivars cannot be distinguished from the dendrogram because we only use 4 pairs of primers with 3 kinds of restriction enzymes. However our research has successfully distinguished diploid and hexaploid cultivars from other cultivars.

Based on this research, we concluded that the CAPS marker gave $45 \%$ of polymorphism (Table 5). That means primers and restriction enzymes used in this research still give low of polymorphic bands. The percentage is smaller than the study before using RAPD marker that has been done by Aristya et al. (2019). However, the CAPS molecular marker can provide complementary data for analysis of the relationship and genetic variation of strawberry cultivars in Banyuroto, Magelang. Although the method is different, the generated data can correlate well with the other data such as cytogenetic and morphological analysis. Each method has its own advantages and disadvantages; the application can be adjusted with the analysis needed.

\section{ACKNOWLEDGMENTS}

We are very grateful to the Ministry of Research, Technology and Higher Education of the Republic of Indonesia for the grant and financial support through the Hikom grant Number 2275/UN.1.P.III/DIT-LIT/LT/2017. We are also very thankful to Banyuroto Village, Magelang, and ICFRI, Malang for the sample used in this research.

\section{REFERENCES}

Akbari M, Wenzl P, Craig V, Carling J, Xia L, Yang S, Uszynski G, Mohler V, Lehmensiek A, Kuchel H, Hayden MJ, Howes N, Sharp P, Vaughan P, Rathmell B, Huttner E, Kilian A. 2006. Diversity arras technology (DArT) for high-throughput profiling of the hexaploid wheat genome. Theor Appl Genet 113 (8): 1409-1420.

Aristya GA, Kasiamdari RS, Setyoningrum R, Larasati B. 2019. Genetic variations of strawberry cultivars of Fragaria $\times$ ananassa and Fragaria vesca based on RAPD. Biodiversitas 20 (3): 770-775.

Aristya GA, Sasongko AB, Hidayati L, Setiawan A. 2017. implementasi inovasi budi daya stroberi di agrowisata Banyuroto Kabupaten Magelang melalui education for sustainable development. Indon $\mathbf{J}$ Commun Engag 2 (2): 125-132.

Britsch L and Grisebach H. 1986. Purification and characterization of (2S)-flavanone 3-hydroxylase from Petunia hybrida. Eur J Biochem 156: $569-577$.
Buckhout-White S, Person C, Medintz IL, Goldman ER. 2018. Restriction enzyme as a target for DNA-based sensing and structural rearrangement. Amer Chem Soc 3: 495-502

Campbell NA, Reece JB, Urry LA, Cain ML, Wasserman SA, Minorsky PA, Jackson RB. 2008. Biology $8^{\text {th }}$ ed. Pearson Education, Inc, USA.

Caverzan A, Passaia G, Rosa SB, Ribeiro CW, Lazzarotto, Pinheiro MM. 2012. Plant responses to stresses: Role of ascorbate peroxidase in the antioxidant protection. Genet Mol Biol 35 (4): 1011-1019.

Chandler CK, Folta K, Dale A, Whitaker VM, Herrington M. 2012. Fruit Breeding. Springer, New York.

Chang S, Puryear J, Cairney J. 1993. A simple and efficient method for isolating RNA from pine trees. Plant Mol Biol Rep 11 (2): 113-116.

Doyle JJ and Doyle JL. 1987. A rapid DNA isolation procedure for small quantities of fresh leaf tissue. Phytochem Bull 19: 11-15.

Edwards D and Batley J. 2010. Plant genome sequencing: applications for crop improvement. Plant Biotechnol J 8 (1): 2-9.

Elena SF, Visser JAGM. 2013. Environmental stress and the effects of the mutation. J Biol 2: 12.

Falah MAF, Yuliastuti P, Hanifah R, Saroyo P, Jumeri. 2018. Quality of fresh strawberry (Fragaria sp. cv. holibert) from Ketep Magelang Central Java and its storage in tropical environment. Jurnal Agroindustri 8 (1): 1-10.

Faedi W, Mourgues F, Rosati C. 2002. Strawberry breeding and varieties: Situation and perspectives. Acta horticulturae 51 (567): 51-59.

Gelinas. 1977. Two Sequence-specific endonucleases from Moraxella bovis. J Mol Biol 114: 169-179.

Hancock JF, Sjulin TM, Lobos GA. 2008. Temperate Fruit Crop Breeding. Springer, Michigan.

Hussain S, Upadhyay P, Das S, Prasad M. 2015. Authentication of medicinal plants by DNA markers. Plant Gene 4: 83-99.

Joshi M and Deshpande JD. 2010. Polymerase chain reaction: methods, principles, and application. Intl J Biomed Res 1 (5): 81-97.

Konieczny A and Ausubel FM. 1993. A procedure for mapping Arabidopsis mutations using co-dominant ecotype-specific PCRbased markers. Plant J 4 (2): 403-410.

Kunihisa M, Fukino N, Matsumoto S. 2005. CAPS markers improved by cluster-specific amplification for identification of octoploid strawberry (Fragaria ananassa Duch.) cultivars, and their disomic inheritance. Theor Appl Genet 110: 1410-1418.

Kunihisa M, Fukino N, Matsumoto S. 2006. Development of PCR-RFLP marker on strawberry and the identification of cultivars and their progeny. Acta Holticulturae 708: 517-522.

Lorenz TC. 2012. Polymerase chain reaction: basic protocol plus troubleshooting and optimization strategies. J Visual Exp 63: 1-15.

Lu KT, Lee HC, Liu FS, Lo CF, Lin JH. 2010. Identification of Ginseng radix in Chinese medicine preparations by nested PCR-DNA sequencing method and nested PCR-restriction fragment length polymorphism. J Food Drug Anal 18: 58-63.

Nunes CF, Ferreira JL, Fernandes MCN, Breves SS, Generoso AL, Soares BDF, Dias MSC, Pascual M, Borem A, Caneado GMA. 2011. An improved method for genomic DNA extraction from strawberry leaves. Ciência Rural 41 (8): 1383-1389.

Puchooa D. 2004. A simple, rapid and efficient method for the extraction of genomic DNA from lychee (Litchi chinensis Sonn.). African J Biotechnol 3 (4): 253-255.

Qi J, Chen Y, Copenhaver GP, Ma H. 2014. Detection of genomic variations and DNA polymorphisms and impact on analysis of meiotic recombination and genetic maping. Proc Natl Acad Sci USA 111 (27): 10007-10012

Roberts RJ, Belfort M, Bestor T, Bhagwat AS. 2003. A nomenclature for restriction enzymes, DNA methyltransferases, homing endonucleases, and their genes. Nucleic Acids Res 31 (7): 1805-1812.

Sharma N, Sharma KP, Gaur RK, Gupta VK. 2011. Role of chitinase in plant defense. Asian J Biochem 6 (1): 29-37.

Shavrukov YN. 2016. CAPS markers in plant biology. Russian J Genet Appl Res 6 (3): 279-287.

Shavrukov YN. 2016. Comparison of SNP and CAPS markers application in genetic research in wheat and barley. BMC Plant Biol 16: 48-51.

Spangler R, Goddard NL, Thaler DS. 2009. Optimizing Taq polymerase concentration for improved signal-to-noise in the broad range detection of low abundance bacteria. PLoS One 4 (9): e7010. DOI: 10.1371/journal.pone.0007010.

Sato S. 1978. A single cleavage of Simian virus 40 (SV40) DNA by a sitespecific endonuclease from Thermus aquaticus Taq I. J Biochem 83 (2): 633-635. 
Suhariyanto. 2015. Statistik Tanaman Sayuran dan Buah-buahan Semusim. Badan Pusat Statistik Indonesia, Jakarta. [Indonesian]

Wang L and Stagemann JP. 2010. Extraction of high-quality RNA from polysaccharide matrices using cetyltrimethylammonium bromide. Biomaterials 31: 1612-1618.

Weising K, Nybom H, Wolff K, Kahl G. 2005. DNA Fingerprinting in Plants. Taylor \& Francis Group, New York.
Wilfinger WW, Mackey K, Chomczynski P. 1997. Effect of pH and ionic strength on the spectrophotometric assessment of nucleic acid purity. Biotechniques 22 (3): 474-478.

Zhu B, Chen THHH, Li, PH. Expression of three osmotin-like protein genes in response to osmotic and fungal infection in potato. Plant Mol Biol 28 (1): 17-26. 